\title{
Technology Strategy and New Technology Based Firms
}

\author{
Héctor Montiel Campos', Itxaso del Palacio Aguirre², Francesc Solé Parellada², \\ José Pablo Nuño de la Parra'
}

\begin{abstract}
A study of the competitive advantage in successful New Technology Based Firms found that their technology strategy played a key role for making these companies improve their competitive advantage. We appealed to the grounded theory as a qualitative strategy to build theory, and to the exploratory case-study methodology to effectively understand this phenomenon in specific contexts as the one represented by small entrepreneurial firms in comparison with large established firms. A suitable comprehension of the different contexts required of a view of technology strategy that is more dynamic than those typically available. We build an explanatory model which integrates and groups the propositions previously developed. We view the study as exploratory to a class of studies aimed at understanding the technology strategy process in new ventures.
\end{abstract}

Keywords: new technology based firms; strategic management; technology strategy; entrepreneurship; innovation; technological opportunities.

\footnotetext{
I Popular and Autonomous University of Puebla State (UPAEP). Postgraduate Interdisciplinary Center (CIP). 2I Sur I I03 Col. Santiago, 72160. Puebla, México. E-mail: hector.montiel@upaep.mx (corresponding author).

2 Polytechnic University of Catalunya (UPC). Department of Management. Campus Sud. Building A Av. Diagonal 649, 08028, Barcelona, Spain.
} 


\section{Introduction}

As early as in 1934, Schumpeter's notion of economic creative destruction already came close to a description of the relationship between technology and entrepreneurship. Some years later, in their discussion of the new competitive landscape, Bettis and Hitt (1995) stated that technology is dramatically changing the basis of competition. The competitive context is increasingly complex, and complexity comes from the point that competition is played out on a wider and wider variety of dimensions (Audretsch, 200I; Westphal, 2002). In this context, D'Aveni (1994) put forward the point that competitive arenas differ, from those where advantages are based on cost and quality to those where timing and know-how are the source of advantages. The sustainability of the advantage is every time more related to the dynamics of competition and to the nature of the underlying innovation (Chiesa and Manzini, 1998). A contextual analysis of the dynamics of organizations indicates that constant pressure is frequently a source of strategic posture (Gibbons and O'Connor, 2003; Hidalgo, 1999).

Within the literature related to research management, development, and innovation there is a remarkable degree of agreement about the need for technology areas to be integrated within strategy-development and planning. The lack of integration often leads to wasteful employment of resources, while integration eventually translates into better performance (Goodman and Lawless, 1994). The rationale for integration is quite broad and includes the promise of more successful product introduction, greater production economies, and protection of products from appropriation by competitors among others. However, technology and strategy represent two very complex schools of thought. The interface between the two areas becomes a concern when technology significantly affects performance (Bulgerman, Maidique and Wheelwright, 200I). The very nature of the technological process adds notorious uncertainty regarding both performance and timing.

Technological innovations are often developed and exploited within large companies or through the creation of New Technology Based Firms (NTBF) (Del Palacio, Solé and Montiel, 2006; Storey and Tether, 1998). While most of the existent literature on technology strategy analyzes the case of large companies or of the organizations in general (Clarke et al, 1995; Drejer, 1996; Davenport,
Campbell-Hunt and Solomon, 2003; Hagedoorn, 1996; Jones and Smith, 1997; Reick and Dickson, 1993; Schilling, 1998), the impact and development of technology strategies on NTBF remains unexplored (Jones, Green and Coombs, 1994). As a result, the generalization and external validity of previous theories based on big corporations have not been still tested. Further, the focuses on the formulation of the technology strategy are only adapted in a limited number of industries and contexts (Pavitt, 1990). In this paper, we aim to test previous theories and build new principles about technology strategy for the case of small companies. Specifically, we based on grounded case-studies in order to better understand the relationship existing between technology strategy and performance of a small company. Grounded research methodologies support that it is necessary to observe a phenomena in a particular context in order to effectively understand and build theories that are "grounded" in the context under consideration (Glaser and Strauss, 1967). In the field of management, these methodologies of research have been widely accepted for analyzing qualitative data and for building theory of positivist nature via systematic analysis of qualitative data collected from multiple case studies of organizations (Eisenhardt, 1989). In our research, the context is represented by small entrepreneurial firms which have been pointed to be a suitable context to engage in a systematic pursuit of theory-building research to generate theory (Tan et al, 2009).

The objective of this paper is, therefore, to improve our understanding of the technology strategy process through an analysis of the results obtained from an exploratory study of multiple cases, conducted in the context of the NTBF. Regarding the organization of the paper, it proceeds as follows. After introduction, we describe briefly a framework to understand the evolution of technology. In the next section, we describe the methodology that follows in the research and show the empirical findings. We shall conclude our paper by discussing the results and introducing the limits, implications and the conclusions conducted in this research.

\section{Literature review}

The literature review in this research was made in parallel to the data gathering and analysis. We find here, an important difference with other research traditions, since 
the exploration of the available literature was conceived in the qualitative perspective (King, Keohane and Verba, 1994). Rather, the simple goal of the literature review is to have a sufficient blueprint for the study. Then, the complete research design will provide us surprisingly strong guidance in determining what data to collect and the strategies for analyzing the data. For this reason, theory development prior to the collection of any case study data is an essential step in doing case studies (Yin, 2002).

Previous literature supports that managers should approach and define strategy methodologies considering that competition is increasingly dynamic and that innovation and competitive advantage creation are intrinsically interrelated (Chiesa and Manzini, 1998; Davenport, Campbell-Hunt and Solomon, 2003). Further, technology strategy might be defined by considering the emergence of new technologies, changes in the dominant strategies and structures of other firms, and shifts in the nature of competition between firms (Afuah and Utterback, 1997; Adner and Levinthal, 2002; Narayanan, 200I). The technological evolution depends on the process through which scientific advance occurs. New advances are made as researchers seek answers to current technical problems, building on prior knowledge that has accumulated (Dosi, 1988). Additionally, social, economic, and political forces might also be considered as they affect the path that technological advance takes, each in somewhat different ways (Szántó, 200I).

A framework that helps us to understand the evolution of technology is the technology S-curve. These graphs are called S-curves because the relationship between effort and performances typically S-shaped. Initially, performance improvements per unit of effort are small because there are many things that you need to learn before you can improve the performance of new technologies significantly (Foster, 1986). According to Utterback and Abernathy (1975), technology evolves through periods of incremental innovation, interrupted by periods of radical innovation. The development of a radical innovation leads to a fluid phase in an industry, during which time many firms enter and compete on the basis of different product designs. Eventually, the firms in the industry converge on a dominant design, which results in the specific phase, during which time only incremental innovation occurs. After a while, the cycle repeats with the development of a new radical innovation, which introduces a new fluid phase.
Although the Utterback and Abernathy model has proven to be quite useful in explaining the evolution of technology, researchers have identified four important modifications that we need to understand. According to Barras (1986), a different model operated in service industries, which he called the "reverse product cycle". Barras said that service industries typically adopt new technologies that are first developed in a goods industry. This adoption of technology from a goods industry leads to the first stage of the reverse product cycle. The adopted technology is employed to make existing services more efficient, thereby reducing costs. These initial innovations are typically incremental improvements. In the second stage of the reverse product cycle, the new technology is used to make the service more effective. The innovations that are introduced at this stage tend to focus on changing the processes used to serve customers, thereby enhancing quality. In the third stage of the reverse product cycle, the technology is used to create new services, making changes at this stage radical. We can see that manufacturing industries start with radical innovation and move to incremental innovation, while service industries start with incremental innovation and move to radical innovation.

The researchers noticed an important puzzle that the Utterback and Abernathy's model could not explain. In some cases, incumbent firms had little trouble transitioning to new radical technologies. Anderson and Tushman (1990) explain why incumbent firms were sometimes able to transition to radical new technologies and other times were not. As Anderson and Tushman explained, established firms are able to transition to a radical technology when that technology is competence-enhancing but fail to do so when it is competence-destroying. On the other hand, Henderson and Clark (1990) noticed that incumbent firms often failed to manage the transition from one technology to another, even when those technologies were not radical. To explain this, Henderson and Clark developed a more fine-grained taxonomy of innovation. In this taxonomy, two additional types of innovation not mentioned by Utterback and Abernathy are present: modular innovation and architectural innovation. Finally, there is another aspect that has not been considered. Christensen (1997) noticed that the incumbent firms that were unable to adopt the radical new technologies were often the very firms that invented them. This pattern suggested that a lack of technological capability could not be the explanation of the firms' failure to transition to the new technology. Christensen believed that 
the source of the problem was the willingness of company's customers to adopt products and services based on the new technology, and not on the company's technical capabilities.

\section{Methodology}

The objective of the research was to obtain comprehensive explanations of the technology strategy process, and to identify the convergence of common themes and patterns through the cases studied (Glaser and Strauss, 1967; Eisenhardt, 1989, 1991; Strauss and Corbin, 1998; Yin, 2002). In order to achieve this goal, we employ a grounded case-study research. We appeal to the grounded theory as a qualitative methodology to build theory (Glaser and Strauss, 1967; Strauss and Corbin, 1998). We use the exploratory case-study research as a proven method to test the internal validity of the propositions (Eisenhardt, 1989; Yin, 2002). The resulting model of research is conceived as a spiral rather than as a linear progress (Berg, 1995) in which the results are sustained in the data and these, in turn, are continually revised with the theory (Miles and Huberman, 1994).

\section{Case study design}

We selected six cases, basing the design of our case study on the idea of theoretical sample (Yin, 2002). The process of selection was facilitated by stakeholders supporting new firm and technology development as part of the Technology-Based Business Incubator Network (TBBIN) at Tecnológico de Monterrey. The TBBIN drives the transformation of highly innovative ideas and projects into high value-added companies applying new knowledge in advanced sectors such as agrobiotechnology, biotechnology, information technology development, the pharmaceutical industry, biomedical engineering, energy, the aerospace industry, and the automotive industry.

We base on previous research to define the selection criteria. The resulting sample consists of six NTBF (I) with an operation track of 3-5 years (Littunen, Storhammar and Nenonen, 1998); (2) an excellent economic-financial performance in relation to other firms in the same industrial sector (Birley and Westhead, 1990); and (3) accounting an annual growth between 20 and $25 \%$ in the years 2007 and 2008 (Fisher and Reuber, 2003). Two additional cases are used as a confirmatory test of the case-study research results (Patton, 200I). These two last NTBF have been in operation for around two years. From a qualitative point of view, these are second order cases, as they follow patterns that have already emerged in previous stages of the investigation. Their analysis provides feasibility to the results obtained previously (Patton, 200I). The Table I shows the information about these cases.

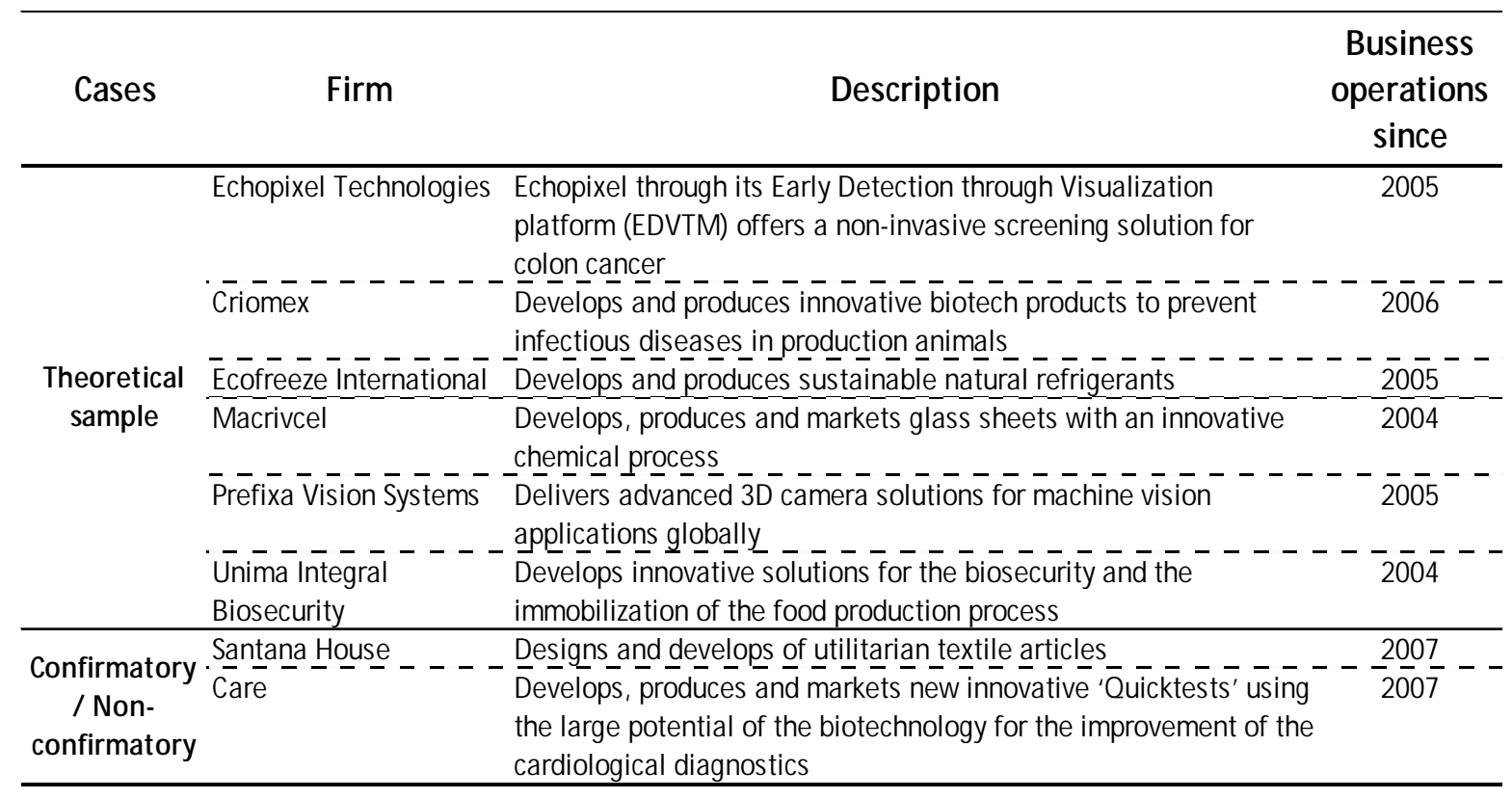

Table I. Cases

ISSN: 07I 8-2724. (http://www.jotmi.org)

Journal of Technology Management \& Innovation (C) Universidad Alberto Hurtado, Facultad de Economía y Negocios 


\section{Data collection}

The data collection for this research was carried out in four stages. The first of the four phases of data collection involved a pilot study consisting of an in-depth, semistructured interview. Three pilot interviews were done before targeting the final sample. This phase included the checking of important documents (official web pages, press packets, product information, documents from clients and suppliers and copies of the business plans) from the cases that were ultimately in the final sample. The second phase consisted of at least three in-depth interviews given to each one of the six NTBF. One interview was made to the General Director and at least other two were done with other main managers in the company. In total, 19 interviews were applied to the theoretical sample. The format of the interview more closely resembled a guided conversation than a series of structured questions. In other words, although a line of specific line of research was followed, the questions that were asked during the interview tended to be more fluid than rigid (Rubin and Rubin, 1995; Holstein and Gubrium, 1995). We reached theoretical saturation with a total of six cases. In other words, the descriptions and explanations were repetitive and that allowed identifying common patterns across the cases (Yin, 2002).

The third phase of the investigation consisted of two activities. The first one took place immediately after the interview. The managers were asked to answer a questionnaire with thirty-two questions in order to test the results obtained during the in-depth interviews. The second activity entailed interviewing seven stakeholders related to the small company in order to get additional information and other possible explanations of the results gathered in the previous interviews. Specifically, we interviewed the managers of the TBBIN as well as the managers of the consulting firms. In the fourth and final phase of our investigation, the same questionnaire that had been given to the six cases that formed the theoretical sample was applied to the two confirmatory cases. The goal was to compare the results of these last two cases with the ones of the first sample in order to confirm the validity of the results used for the explanatory model. The feedback obtained of these two cases was included in the final results of the investigation.

\section{Data analysis}

Our investigation was designed as a study of multiple cases. The general strategy for the processing of the data followed the proposal of codification put forth by Strauss and Corbin (1998) as a means of generating theory. The analysis of the data was iterative with its collection, which facilitated the creation of themes, standards and theoretical models. They were continually modified so that new data and themes could be incorporated, as well as the most recent ideas proposed by researchers (Miles and Huberman, 1994).

The organization of the available data followed the three stages proposed by Strauss and Corbin (1998). The first stage was basically descriptive, and all the information gathered was represented in a simple text in order to provide a better understanding. In this stage the descriptive categories appeared. A descriptive category is a labeled phenomenon, and it is the abstract representation of an event, object or action significant in the data (Strauss and Corbin, 1998). The second stage involved dividing the initial series of data that had been collected into segments. These segments were defined by using the descriptive categories that had emerged from the data itself, they allowed us to regroup the information and read it in a different way. It was in this that the relational categories appeared which linked two or more descriptive categories to each other. In the third stage, we structured the information based on the interrelation of the descriptive categories that had been linked by the relational categories. We made a selective categorization to identify several core categories that articulate the final explanatory model.

While analyzing our data, we followed the suggestions of Yin (2002) as to the four aspects that insure the quality of an investigation. The reliability of our research was obtained through the development of a protocol and a database composed of the findings of the investigation itself. Its validity was achieved by using different sources of evidence, the creation of a chain of evidence and the participation of stakeholders who checked the results (Yin, 2002). The information gathered from the cases was compared to the propositions that continually emerged in order to determine the degree to which they were consistent, following the logic of constant comparison (Miles and Huberman, 1994). 


\section{Results}

The result of this investigation is a theoretical model of exploratory nature, in which previously developed propositions can be grouped and related in a new way. Langley (1999) sets forth that the interaction of a relatively limited number of simple decisive elements can generate complexity, if they are all considered at the same time while analyzing a phenomenon. This idea leads us to suggest that relatively parsimonious theoretical formulations can help us make sense of the complexity observed in the processing of the data. Such premises bring out the central challenge of this research project: how can we move from the diversity of the data towards a theoretical understanding of it? While such a theory would not contain the richness, dynamism and complexity of the data, it would be understandable and potentially useful for others.
In view of these arguments, we have sought to create a model that encompasses specificity, generality and simplicity (Langley, 1999). It seems unreasonable to expect that the model be as equally rich as all of the experiences of the firms. Every model describes an approach, which simplifies the actual experience (Fiet, 1996). In the next section, we show the model and the factors that influence the technology strategy process.

\section{Towards a model of the technology strategy process in NTBF}

We can identify four stages in the technology strategy process of a NTBF (Figure I). Initially, the firm must recognize the dynamic of the context in which it operates, so that it knows the different kinds of strategies that are possible to undertake. The next step is the change of the structure in order to implement the strategies. Finally, the firm must find a mechanism to protect the profits.

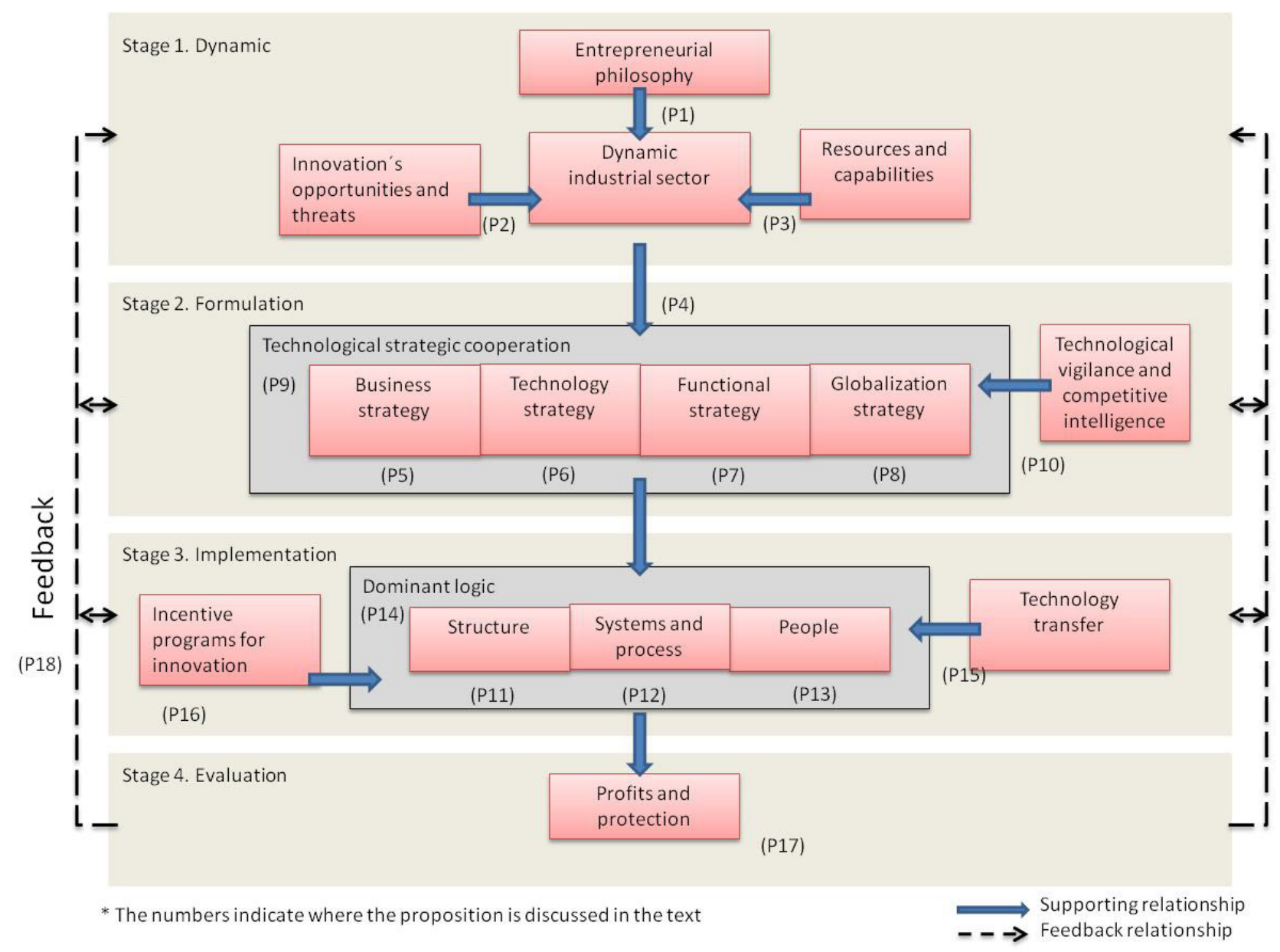

Figure I. The technology strategy process

ISSN: 07/8-2724. (http://www.jotmi.org) Journal of Technology Management \& Innovation (c) Universidad Alberto Hurtado, Facultad de Economía y Negocios 
The NTBF can show the importance of the innovation through its goals and these are different from one firm to another. In some firms, the innovation is in the essence of products and services; therefore, the business philosophy must demonstrate the firm's commitment with technological innovation (Proposition I). The first step so that the company achieves its goals is to identify the related actors (suppliers, customers, competitors, complementary innovators, related industries, etc.). Likewise, it should explore externally (technological discontinuities, elimination of controls and regulations, macroeconomic movements, clients' changing expectations, among others), and internally (chain of value of the own company) to the company with the purpose of detecting any idea or invention that can become an opportunity or threat for the firm's business philosophy (Proposition 2). Once an idea or invention has been detected and its rational base has been understood, as well as its applications, the NTBF must clarify two matters: the necessary capabilities to exploit the innovation; and the capabilities of possible collaborator-competitors (Proposition 3). Next, the firm selects a place in which to obtain profits, that is to say, supplier, manufacturer, customer or complementary innovator. The place in which profits would be obtained should be in agreement with the global strategy of the firm (Proposition 4). This group of actions and choices can be identified in the first phase of the model: the dynamic.

In the second stage of the technology strategy process, the firm has to decide its business strategy (cost leadership strategy, differentiation strategy or focus strategy) to solve problems or necessities in the market (Proposition 5). Also, the firm determines its technology strategy. It could be the first in introducing the product (offensive strategy), or it could follow a strategy where others act first (following strategy). The technology strategy is a function of firm's capabilities and strategic intention (Proposition 6). After having defined the business strategy and the technology strategy, the firm has to make changes in its organization and assign resources to the different functions along its value chain (Proposition 7). An important aspect in the selection of the technological innovation is related to the reflection of when and how to pass to a global level. The firm can be global if it locates some activities or functions of its value chain in others countries. The main benefit of being a global firm is having the ability to make a better use of the technological knowledge and of the market (Proposition 8). In order to carry out, in an easy way, these four strategies, the NTBF makes use of the strategic cooperation with other organizations because it does not have the resources and capabilities that allow it to do it alone (Proposition 9). Due to the necessity of a strategic cooperation, it is fundamental that the firm watches over what is happening in its competitive context. This action will produce information for the firm, and the firm must be able to use it for commercial purposes (Proposition 10). In the global vision of the model, this phase can be identified as formulation.

In the third stage, the firm will establish an organizational structure to coordinate its activities, and then accelerate the development of the products (Proposition II). Likewise, the firm should create systems to supervise the agreements and the flow of information for decision making (Proposition 12). Finally, the activity in the NTBF requires people with knowledge and capacities that sustain the diverse activities in the value chain (Proposition 13). Then, the business manager has to make a synergy between structure, systems and people in order to reach the goals (Proposition 14). After that, the business manager knows the firm's strengths and weaknesses and would like to formalize any technology transfer agreement (Proposition 15). At the same time, the firm could obtain resources from the government to improve any activity in the value chain (Proposition 16). Here the implementation, the third stage of the model, concludes.

The fourth stage of our model corresponds to evaluation. In this stage the firm wants to reach the competitive advantage. With this purpose, the firm uses strategies in the different activities of its value chain such as obstruction, race and association (Proposition 17). The presentation of this process of development in an ordered, sequenced and segmented way does not mean that the different phases are independent "compartments" in fact each one is completely dependent on the others. This process is cyclical and iterative. In each one of the phases, the manager reflects upon the opportunity, which can lead him to recognize additional opportunities and make adjustments to his previous vision (Proposition 18). 


\section{Discussion}

The model shows the main constructs of a middle-range theory (Eisenhardt, 1989), substantial theory (Glaser and Strauss, 1967) or explanatory model (Yin, 2002). This model explains the technology strategy process in the first years of business operations in the NTBF. The model suggests actions in top-down order that the firm carries out to protect its profits, and a feedback circuit to encourage or reconfigure objectives or strategies, just as it is shown in the Figure I. It is important to mention that this process is better when there is the coincidence of various factors. Firstly, the incremental innovation propitiates a relatively stable context and with little uncertainty (Von Hippel, 1994). On the other hand, the rationality is very important because the managers must consider all the possible contingencies. We suppose that the model will not be able explain the reality if there is a radical innovation, because such an innovation is uncertain and complex (White and Bruton, 2007).

The sequence in the model does not eliminate the possibility that the innovation process can begin in any part. For example, in response to technological vigilance the firm can change its position in order to select a place in which to obtain profits (Gatignon, et al., 1997; Zahra and Bogner, 2000). At the same time, the firm must reflect if it has the necessary capabilities to take advantage of the innovation (Tidd and Trewalla, 1997). Otherwise, a change in the dominant logic of the firm can generate a different point of view in the strategic cooperation (Ford and Thomas, 1997; Vyas, Shelburn and Rogers, 1995), and this can change the business strategy too (Bettis and Prahalad, 1995; Fontes and Coombs, 1997). Finally, we can find eighteen theoretical propositions, which connect the different constructs in the model. Each proposition could be different for each case that is studied, and this patter makes the model eclectic and integrative.

\section{Limitations and implications}

Although the design of this investigation followed a constructivist approach, it is worth mentioning some aspects that should be kept in mind. The results of this study need to be viewed in their context and should be treated carefully. The study of the technology strategy process was carried out around the reality of six NTBF, which have obtained a good performance during their first years of business activities. This means that our model is limited to explain the reality of the firms that we are studying. The only generalization allowed is the theoretical generalization, because we use the results to link discoveries with concepts or existent theories (Yin, 2002). Exploratory research can be conceived in its most general sense as a project that is intentional and systematic. At the same time, the way in which the project was designed allowed us to maximize the number of generalizations discovered, which facilitates the description and understanding of a phenomenon that is not sufficiently clear (Stebbins, 200I). Exploratory research also provides us with the opportunity to develop ideas for future projects (Yin, 2002). The precision, integrity and relative importance of the theoretical propositions represent another future project. This investigation would necessarily lead us to propose that the model has to be validated, but to carry out such a process, we would have to resort to another proposal and research model, since the creation and validation of theories have traditionally been considered as different purposes of research (Dubin, 1978). Although we initially proposed to present a holistic study, a future project could focus on studying only one part of the model more in-depth. In this way, each one of the propositions that was generated would acquire importance in a specific way. The individual propositions or the sum of them could then represent a new line of research.

\section{Conclusion}

The model shows the technology strategy process and for the manager this process represents a learning process that allows him to perfect himself in real time and for future events. For this reason, the model reaffirms the existence of operative and strategic feedback (Maidique and Zirger, 1985). In the successful management of the firm, a trade-off between the uncertainty of technology and the potential strategic benefits of technology is necessary. The value of good strategy is the shield it provides against competition, ensuring a measure of certainty and allowing an organization to create effective approaches to the needs of the marketplace. Technology is one of the key activities which promise such benefits. The organizational costs of employing technological elements within technology strategy are accompanied by the need to cope with an added measure of uncertainty and disruption. This requires a reconsideration of the traditional planning process and a 
careful integration of the paradigms of the strategists with the paradigms of the technologists.

\section{References}

ADNER, R., Levinthal, D.A. (2002) The emergence of emerging technologies. California Management Review, 45(I), 50-66.

AFUAH, A.N., Utterback, J.M. (1997) Responding to structural industry changes: A technological evolution perspective. Industrial and Corporate Change, 6(I), 183-202.

ANDERSON, P., Tushman, M.L. (1990) Technological discontinuities and dominant designs: a cyclical model of technological change. Administrative Science Quarterly, 35(4), 604-633.

AUDRETSCH, D.B. (200I) Research issues relating structure, competition, and performance of small technology-based firms. Small Business Economics, 16(I), 3751.

BARRAS, R. (1986) Towards a theory of innovation in services. Research Policy, I5(4), I6I-I73.

BERG, B.L. (1995) Qualitative research methods for the social sciences. Allyn and Bacon, Boston.

BETTIS, R., Hitt, M. (1995) The new competitive landscape. Strategic Management Journal, I6(I), 7-19.

BETTIS, R.A, Prahalad, C.K. (1995) The dominant logic: retrospective and extension. Strategic Management Journal, I6(I), 5-I4.

BIRLEY, S., Westhead, P. (1990) Growth and performance contrasts between "types" of small firms. Strategic Management Journal, I I (7), 535-557.

BULGERMAN, R., Maidique, M., Wheelwright, S. (200I) Strategic Management of Technology and Innovation. $3^{\text {rd }}$ Ed. Mc Graw-Hill, Boston.

CHIESA, V., Manzini, R. (1998) Towards a framework for dynamic technology strategy. Technology Analysis and Strategic Management. IO(I), I I I-I 29.
CHRISTENSEN, C. (1997) The innovator's dilemma. Harvard Business School Press, Boston.

CLARKE, K., Ford, D., Saren, M., Thomas, R. (1995) Technology strategy in UK firms. Technology Analysis and Strategic Management, 7(2), 169-190.

D'AVENI, R. (1994) Hypercompetitive rivalries -Competing in highly dynamic environments. Free Press, New York.

DAVENPORT, S., Campbell-Hunt, C. and Solomon, J. (2003) The dynamics of technology strategy: an exploratory study, R\&D Management, 33(5), 48I-499.

DEL PALACIO, A.I., Solé, P.F., Montiel, C.H. (2006) University Spin-offs programmes: how can they support the NTBF creation?. International Entrepreneurship and Management Journal, 2(2), I57-I72.

DOSI, G. (1988) Sources, procedures, and microeconomics effects of innovation. Journal of Economic Literature, 26(3), II20-II7I.

DREJER, A. (1996) Frameworks for the management of technology: towards a contingent approach. Technology Analysis and Strategic Management, 8(I), 9-20.

DUBIN, R. (1978) Theory building. $2^{\text {nd }}$ ed. Free Press, New York.

EISENHARDT, K.M. (1989) Building theories from case study research. Academy of Management Review, 14(4), 532550.

EISENHARDT, K.M. (199I) Better stories and better constructs: the case for rigor and comparative logic. Academy of Management Review, 16(3), 620-627.

FIET, O.J. (1996) The informational basis of entrepreneurial discovery. Small Business Economics. 8, 419430.

FISHER, E., Reuber, A.R. (2003) Public support for rapid growth firms: a comparison of the views of founders, government policy makers and private sector resource providers. Journal of Small Business Management, 4I(4), 346-365. 
FONTES, M., Coombs, R. (1997) The coincidence of technology and market objectives in the internationalization of new technology-based firms. International Small Business Journal, 15(4), 14-35.

FORD, D., Thomas, R. (1997) Technology strategy in networks. International Journal of Technology Management, 14(6-8), 596-612.

FOSTER, R. (1986). Innovation: the attacker's advantage. Summit Books, New York.

GATIGNON, H., Roberston, T., Fein, A.J. (1997) Incumbent defense strategies against new product entry. International Journal of Research in Marketing, 14(2), 163-I76.

GLASER, B., Strauss, A. (1967) The discovery of grounded theory: strategies for qualitative research. Aldine, Chicago.

GIBBONS, P.T., O'Connor, T. (2003) Strategic posture, technology strategy and performance among small firms. Journal of Enterprising Culture, I I(2), I3।-I46.

GOODMAN, R.A. , Lawless, M.W. (1994) Technology and strategy. Oxford University Press.

HAGEDOORN, J. (1996) Trends and patterns in strategic technology partnering since the early seventies. Review of Industrial Organization, II, 60I-6I6.

HENDERSON, R., Clark, K. (1990) Architectural innovation: the reconfiguration of existing product technologies and the future of established firms. Administrative Science Quarterly, 35(I), 9-30.

HIDALGO, A. (1999) La gestión de la tecnología como factor estratégico de la competitividad industrial. Economía Industrial, 330, 43-54.

HOLSTEIN, J.A., Gubrium, J.F. (1995) The active interview. Sage, Thousand Oaks.

JONES, O., Green, K., Coombs, R. (1994) Technology management: developing a critical perspective. International Journal of Technology Management, 9(2), |56-|7|.

JONES, O., Smith, D. (1997) Strategic technology management in a mid-corporate firm: the case of otter controls. Journal of Management Studies, 34(4), 5 I I-536.
KING, G., Keohane, R.O., Verba, S. (1994) Designing social inquiry: scientific inference in qualitative research. Princeton University Press, Princeton.

LANGLEY, A. (1999) Strategies for theorizing from process data. Academy of Management Review, 24(4), 69I710.

LITTUNEN, H., Storhammar, E., Nenonen, T. (1998) The survival of firms over the critical first 3 year and the local environment. Entrepreneurship and Regional Development, 10(3), 189-203.

MAIDIQUE, M.A., Zirger, B.J. (1985) The new product learning cycle. Research Policy, I4(6), 299-3I3.

MILES, M. and Huberman, A. (1994) Qualitative data analysis. Sage, Thousand Oaks.

NARAYAN, V. (200I) Managing technology and innovation for competitive advantage. Prentice Hall, New Jersey.

PATTON, M.Q. (200I) Quality research and evaluation methods. 3th ed. Sage, Thousand Oaks.

PAVITT, K. (1990) What we know about the strategic management of technology. California Management Review, 32(3), 17-26.

REICK, R., Dickson, K. (1993) A model of technology strategy. Technology Analysis and Strategic Management, 5(4), $397-412$.

RUBIN, H.J., Rubin, I.S. (1995) Qualitative interviewing: the art of hearing data. Sage, Thousand Oaks.

SCHILLING, M. (1998) Technological lockout: an integrative model of economic and strategic factors driving technology success and failure. Academy of Management Review, 23(2), 267-284.

SCHUMPETER, J.A. (1934) The theory of economic development. Harvard University Press, Cambridge, MA.

STEBBINS, R.A. (200I) Exploratory research in the social sciences. Sage, Thousand Oaks. 
STRAUSS, A., Corbin, J. (1998) Basics of qualitative research - Techniques and procedures for developing grounded theory. $2^{\text {nd }}$ ed. Sage, Thousand Oaks.

STOREY, D.J., Tether, B.S. (1998) New technology-based firms in the European Union: An introduction. Research Policy, 26(9), 933-947.

SZÁNTÓ, B. (200I) The paradigm of globalism. Technovation, 2I(10), 673-687.

TAN, J., Fisher, E., Mitchell, R, Phan, P. (2009) At the center of the action: Innovation and technology strategy research in the small business setting. Journal of Small Business Management, 47(3), 233-262.

TIDD, J., Trewalla, M. (1997) Organizational and technological antecedents for knowledge acquisition and learning. R\&D Management, 27(4), 359-375.

UTTERBACK, J.M., Abernathy, W.J. (1975) A dynamic model of process and product innovations. Omega, 3, 639659.

VON HIPPEL, E. (1994) "Sticky information and the locus of problem solving: implications for innovation. Management Science, 40(4), 429-439.

VYAS, N.M., Shelburn, W.L., Rogers, D.C. (1995) An analysis of strategic alliances: forms, functions and framework. Journal of Business and Industrial Marketing, 10(3), 47-60.

WESTPHAL, L.E. (2002) Technology strategies for economic development in a fast changing global economy. Economics of Innovation and New Technology, II (4-5), 275320

WHITE, M.A., Bruton, G.D. (2007) The management of technology and innovation. Thomson. Canada.

YIN, R.K. (2002) Case Study Research - Design and Methods, 3th ed. Sage, Thousand Oaks.

ZAHRA, S., Bogner, W. (2000) Technology strategy and software new ventures' performance: exploring the moderating effect of the competitive environment. Journal of Business Venturing, 15(2), I35-173.

\section{About the authors}

Héctor Montiel is Professor at the Popular and Autonomous University of Puebla State (UPAEP), at Postgraduate Interdisciplinary Center (CIP). His subject research is entrepreneurship in dimensions of opportunity, strategy and technology. He is member of the National Researchers System (SNI) of the National Council of Science and Technology (CONACYT) in Mexico.

Itxaso del Palacio is a doctor candidate in the Department of Management at Polytechnic University of Catalunya (UPC). Her research interests include entrepreneurship and innovation.

Francesc Solé is Professor at the Polytechnic University of Catalunya (UPC), at Department of Management. His current research is focused on entrepreneurship and innovation. Dr. Solé is Director of the Innova Program at UPC and he is Vice-President of the Foundation of Knowledge and Development in Barcelona, Spain.

José Pablo Nuño is Vice-President of Postgraduate and Research at the Popular and Autonomous University of Puebla State (UPAEP). His subject research is strategic management 